
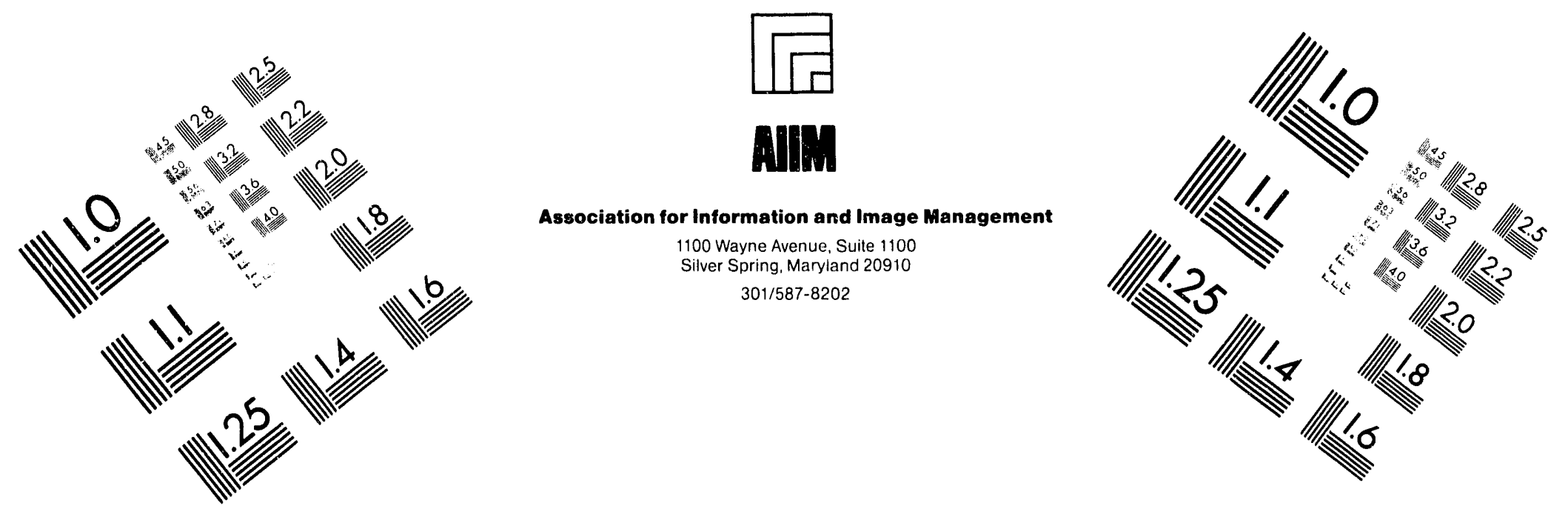

\title{
Centimeter
}

$\begin{array}{llllllllllllllll}1 & 2 & 3 & 4 & 5 & 6 & 7 & 8 & 9 & 10 & 11 & 12 & 13 & 14 & 15 & \mathrm{~mm}\end{array}$

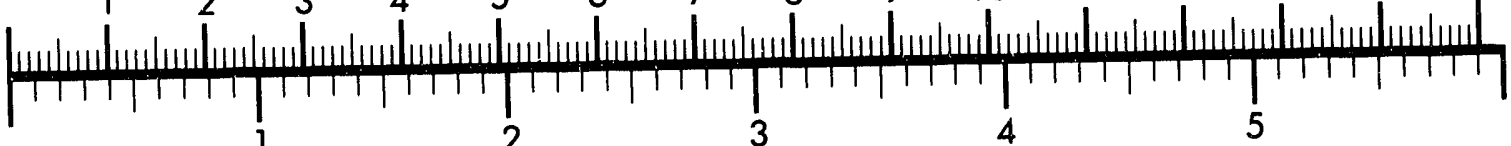
Inches
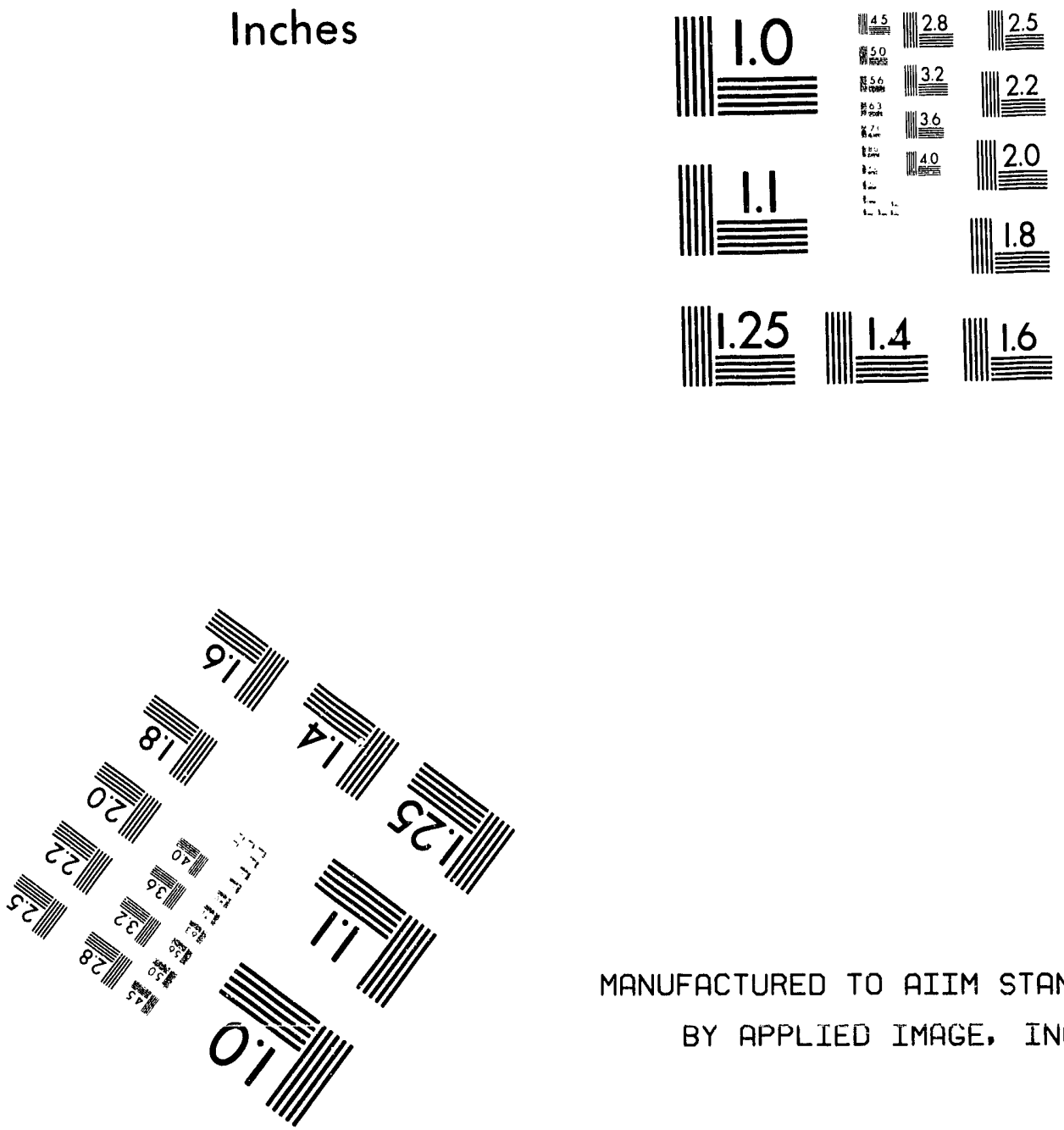

MANUFACTURED TO AIIM STANDARDS

BY APPLIED IMAGE, INC.

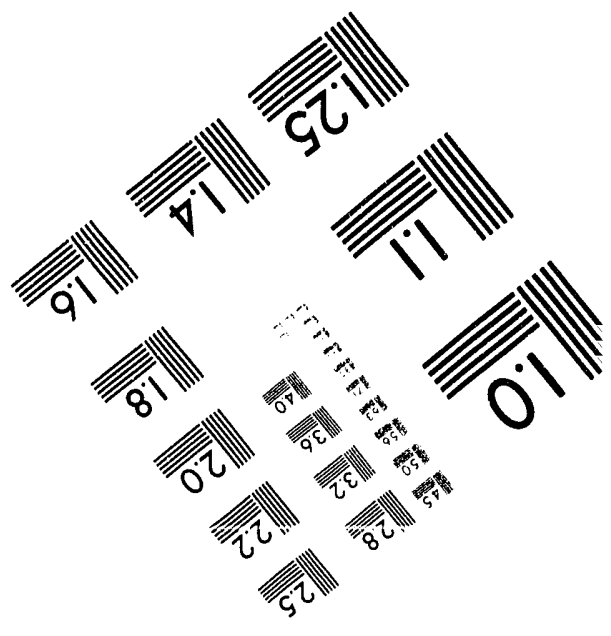



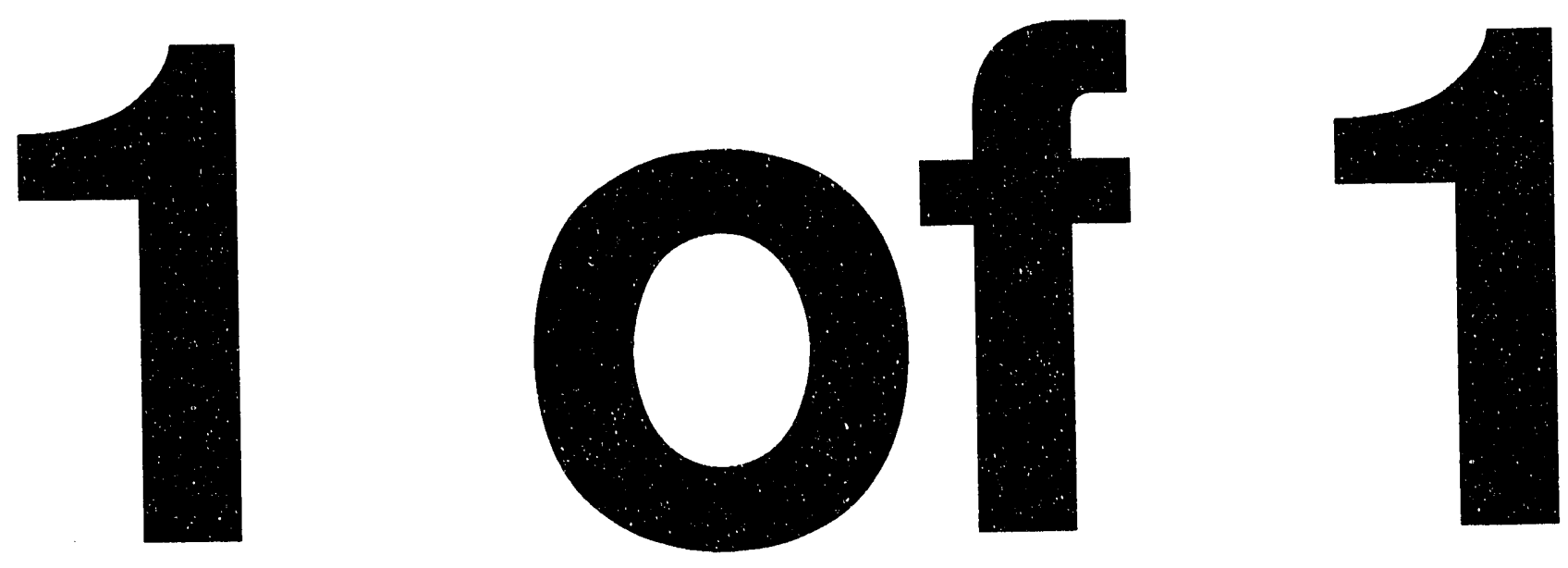


$$
D O E / C H / 10324-T \text { TI4 }
$$

\section{Lessons Learned by Southern States in Designating Alternative Routes}

Prepared for the U.S. Department of Energy under Cooperative Agreement DE-FCOZ-87CH10324

by the

Southern States Energy Board 3091 Governors Lakes Drive Suite 400 Norcross, Georgia 30071

(404) 242-7712

August 1989 
Lessons Learned by Southern States in Designating Alternative Routes

Table of Contents

Introduction

Arkansas

Kentucky

Maryland 6

Tennessee 8

Virginia 9

References 


\section{Entroduction}

The purpose of this report is to discuss the "lessons learned" by the five states within the southern region that have designated alternative or preferred routes under the regulations of the Department of Transportation (DOT) established for the transportation of radioactive materials. The document was prepared by reviewing applicable federal laws and regulations, examining state reports and documents and contacting state officials and routing agencies involved in making routing decisions. In undertaking this project, the Southern States Energy Board hopes to reveal the process used by states that have designated alternative routes and thereby share their experiences (i.e., lessons learned) with other southern states that have yet to make designations.

Under DOT regulations (49 CFR 177.826), carriers of highway route controlled quantities of radioactive materials (which include spent nuclear fuel and high-level waste) must use preferred routes selected to reduce time in transit. Such preferred routes consist of (1) an interstate system highway with use of an interstate system bypass or beltway around cities when available, and (2) alternate routes selected by a "state routing agency."

A state routing agency may designate an alternative or preferred route for highway route controlled quantity shipments of radioactive materials in accordance with the U.S. Department of Transportation's (DOTs) Guidelines for Selecting Preferred Highway Routes for Large Quantity Shipments of Radioactive Materials or an "equivalent routing analysis" that adequately considers overall risk to the public. (For more information on specific alternative routes and contacts within the southern states, see the Southern States Energy Board's (SSEB's) companion report, State Alternative Route Designations). Once designations have been made and notice of the designations has been provided to the DOT, carriers transporting radioactive materials within a specified class of material must use these preferred routes. Under the DOT nuclear routing rule (49 CFR Part 177.825 or HM-164), carriers of highway route controlled quantity radioactive material must use preferred routes. A preferred route is an interstate or state highway, or a state-designated alternative. A state-designated alternative must be disclosed to DOT to become effective. 
While a state may choose to designate alternative routes, there is no absolute requirement that a state make such designations. Indeed, many southern states have chosen not to make designations. These states have decided to use the interstate system highways. Only five states, Arkansas, Kentucky, Maryland, Tennessee and Virginia, have chosen to designate alternative routes. Each of these states and the lesson(s) learned by the state's routing officials is discussed within these pages.

In some cases, alternative routes were established without the aid of a formal risk analysis envisioned by HM-164, the DOT rulemaking authority for routing. Even in situations where a structured, technical analysis did not occur, however, most states assembled a "core" working group to discuss routing issues. Often, the group consisted not only of the state's routing agency staff and officials, but also the state police, emergency services or emergency management agency, the state's department of transportation and so forth.

A number of states chose to conduct fairly detailed risk analyses; one state, Virginia, even spent $\$ 98,000$ on an outside contractor study. Most states chose to perform their own study "in-house" pursuant to DOTs Guidelines, mentioned above, thereby reducing the cost of contractor studies.

The lessons learned by states that have designated alternative routes are, among other things, that it is extremely important that the proper routing agency or agencies be identified and brought together for consultation. Many states expressed their confusion over which agency should take the lead in designating alternative routes. The identification of the appropriate agency or agencies allowed the process to run efficiently and in an organized manner.

Also, states indicated that it was important that guidelines for designating alternative routes be established and followed. Those states that did not follow DOTs guidelines expressed frustration at the process of formulating ther own strategy. Sometimes a state simply examined a map of the interstate highway system. Other states indicated that the DOT guidelines were the most appropriate means of choosing the necessary routes.

Finally, the states emphasized the need for DOT to communicate requirements to them in a timely and effective manner. States such as Maryland and Virginia were under the impression that their alternative routes had been filed 
with the DOT when, in fact, this was not the case. The states vowed to comply with the department's regulations but noted that they were unaware of their non-compliance or they would have notified DOT earlier. The primary lesson learned, therefore, was that communication among and between state agencies and DOT is integral to the establishment of alternative routes. 


\section{Arkansas}

Routes were established after consultations among and between a number of state agencies, including the Arkansas Transportation Commission and the state police. Additionally, valuable input was provided by the emergency response agencies located in Little Rock, North Little Rock and Pulaski County. There is not a single agency in the state at present, however, that exercises authority to designate alternative routes.

State designated alternative routes are:

Memphis to Fort Smith: - I-40 to the Oklahoma state line.

Memphis to Texarkana - I-40

Memphis - I-40 to I-440 in North Little Rock thru Little Rock to I-30.

I-440 to I-30 (in lieu of I-430, I-630 and that portion of I-30 connecting $\mathrm{I}-40$ and $\mathrm{I}-440)$.

I-30 to the Texas state line.

For shipments from the north take I-55 to I-40.

For routes around Little Rock take I-440 to I-40 or I-30.

\section{Lessons Learned:}

Arkansas did not employ DOTs Guidelines for Selecting Preferred Routes for Large Quantity Shipments of Radioactive Materials as the basis for designating routes and, in fact, it is unclear what guidelines were used. The state police indicated that officials from the agencies mentioned above examined a map of Arkansas routes and selected the interstate highway systems listed there. The state intends to review the route designation process outlined in HM-164 and revise existing alternative routes in a manner consistent with DOTs Guidelines or an equivalent routing analysis. To date, however, the state has not consulted with DOT. 


\section{Kentucky}

Authority to designate alternative routes for the state of Kentucky is vested in the Kentucky Department of Transportation. The designation of existing alternative routes was accomplished in meetings of a core group of state agencies headed by the state DOT and including the radiation control office in the Cabinet for Human Resources and the Division of Disaster and Emergency Services of the Department of Military Affairs.

Kentucky employed a straightforward approach to designating routes that considered both population density and road conditions. For example, road conditions dictated the selection of I-64 through Louisville as opposed to the I-264 beltway owing to extreme congestion and construction work in and around the beltway. The state has not addressed the question of designating alternative routes once construction is completed, although officials are not likely to allow large numbers of shipments through downtown Louisville once the congestion is alleviated.

Alternative routes for Kentucky are: I-64 is the East/West route (with I-264 in the Louisville area prohibited from being used because I- 65 is being designated as an alternative route); I-24 is the western Kentucky North/South route; I-65 is the central North/South route through Louisville (with I-264 in the Louisville area prohibited from being used because I-65 is being designated as an alternative route); I-71 is a North central route (with I-264 in the Louisville area prohibited from being used because $I-71$ is being designated as an alternative route); I-71/I-75 is the central North/South route past Lexington and to and from Cincinnati except that I-275 in the Covington-Newport-Cincinnati area must be used as an alternative route to $1-71 / 1-75$ from the junction of I-71/I-75 with I-275 to the Ohio state line; and I-471 in the Newport area cannot be used because the beltway, I-275, is required to be used instead.

\section{Lessons Learned:}

Kentucky attributes the successful designation of alternative routes to the communication between state agencies. Face-to-face meetings allowed for input by affected agencies. Also, the state will sometimes use an interstate highway through a city, as is the case in the Louisville area, when the beltway around the city is undergoing construction or is otherwise too congested. 


\section{Maryland}

In 1981, a core group of 10 state agencies, led by the Maryland Department of Transportation, issued a study entitled Preferred Highway Routes for Large Quantity Shipments of Radioactive Materials to devise an acceptable highway routing plan for the shipment of radioactive materials through the state. Using the DOT's Guidelines the core group studied avallable routes and made designations based on factors such as road quality and population density. The results of this analysis indicated that use of the proposed non-interstate routes posed no greater risk than the use of the interstate highway system.

Alternative routes listed by the state are U.S. Highway 301 from Delaware to Virginia and Routes 40 and 48 to Morgantown, West Virginia. DOT has no record of these listings.

\section{Lessons Learned:}

The process of establishing alternative routes outlined above was enhanced owing to the direct input of a number of state agencies. The fact that diverse agencies of state government acted in concert rather than as separate entities expedited the process.

One major lesson learned is that route selection must be revised periodically to account for changes in road conditions and population density. For example, since the initial designation of routes, some portions of Highway 301 have become more densely populated. Although the risk factors for the overall routes have not changed significantly, developments over the eight years have underscored the need for periodic review. At present, there is no mechanism established for such a periodic review and modification of routes.

In many cases beltways designed to move traffic around populated areas have become heavily congested. Owing to shifts in the population, parallel interstate routes may be considered. For example, in Maryland 1-81 may be a more desirable route than I-95 since I-81 is less congested and, therefore, may avoid time delays and heavy traffic, which may in turn decrease the risk of an accident. 
Maryland also emphasized that the route selection process would be enhanced by face-to-face consultations with adjacent states as opposed to paper correspondence. 


\section{Tennessee}

The Tennessee Public Service Commission is the lead state agency involved in the routing of high-level radioactive materials. Alternative routes presently in use in Tennessee were originally established due to the desir? to reroute all truck traffic around Knoxville during the Tennessee World's Fair. This practice remained in force after the conclusion of the fair.

Beginning in 1985, the PSC staff conducted an analysis of potential routes as the initial step in the rulemaking process. This analysis considered a number of factors similar to those in DOT guidelines, including population density, road conditions, noise levels and access to the roadway in the event of an accident. The staff then proposed alternative routes for the transportation of hazardous materials, including high-level radioactive waste, based on the statistical data generated by this analysis.

In 1987, the PSC held public hearings on the designation of alternative routes. As a result of these proceedings, the commission promulgated rules restricting the routing of vehicles transporting hazardous materials in Knox County.

The alternative route in Tennessee is I-640 (in lieu of I-40 in the Knoxville area). This route has been filed with the U.S. Department of Transportation in compliance with HM-164A.

\section{Lessons Learned:}

The risk analysis and subsequent public hearings allowed for the input of interested parties prior to adoption of the proposed route. 


\section{Virginia}

Alternative routes have been established for Virginia using both outside contractor and internally-generated studies. No state agency has been vested with statutory authority to designate alternative routes in the state; however, the Department of Emergency Services has assumed such authorit.r.

The internally-generated studies were based primarily on the DOT's Guidelines. These studies were performed by Emergency Services in cooperation with the state radiation health agency and in conjunction with the Nuclear Regulatory Commission (NRC) and were accomplished in part by actually running the proposed route and conducting "table top" analyses of the proposed routes. The use of internally-generated studies, however, was eventually challenged by several interest groups based on the fact that the agency charged with responsibility for designating routes was also conducting the study. These groups favored the use of an independently-conducted routing study.

The state subsequently employed a contractor to recommend alternative routes. The contractor's report, like the internally-generated study, was based on the risk analysis methodology contained in DOT's Guidelines.

Alternative routes for Virginia are: US Route 15 north and south between the Maryland state line and I-66; VA Route 207 between Port Royal and I-95; US Route 29 north and south between I-66 and I-64; US Route 17 north and south from US 301 to I-81; US Route 301 north and south from the Maryland state line to VA Route 207; VA Route 208 from I-95 to US Route 522; US Route 522 from VA Route 208 to I-64; VA Route 155 from I-64 to VA Route 5 at Charles City; VA Route 5 east and west from Charles City to VA Route 156 south; VA Route 156 north and south to VA Route 10; VA Route 10 east and west to US Route 58; US 460 east and west between Petersburg and US 58; US 58 east and west from Portsmouth to I-95; US 17/258 from I-64 to VA Route 10; US 460 east and west between Lynchburg (Mt. Athos Road) and US 220 Alt. to US 11 to I-81; and US 460 east and west from the West Virginia state line to VA 100 at Pearisburg to Dublin to I-81. 


\section{Lessons Learned:}

Cost is a major drawback to the use of contractor-generated studies. The study conducted for Virginia cost approximately $\$ 98,000$.

In Virginia, alternative route designations have been part of an on-going process; several of the initial routes have been replaced owing to changes in road conditions and population density. For example, the state, in consultation with the NRC, now bans shipments over I-77 to and from West Virginia. Additionally, new routes have been designated on an as-needed basis.

Virginia believes that the routes presently in use are sufficient and no significant changes are andicipated in the near future. 


\section{References}

Annual Radioactive Materials Transportation Legal Developments Report. Battelle Project Management Division, Office of Transportation Systems and Planning, Columbus, Ohio. September 1988.

"Governors' Designees Receiving Advance Notification of Transportation of Nuclear Waste." Eederal Register 53 (June 30, 1988): 24818-24820.

Guidelines for Selecting Preferred Highway Routes for Large Quantity Shipments of Radioactive Materials. U.S. Department of Transportation, Research, and Special Programs Administration, Washington, D.C. June 1981. (DOT RSPA/MTB-81/5).

HM-164: Radioactive Materials: Routing and Driver Training Requirements. Sandia National Laboratories, Albuquerque, New Mexico. March 1986. (SAND-85-7160).

Inconsistency Ruling and Applications under \$112/a) of the Hazardous Materials Transportation Act. U.S. Department of Transportation, Research and Special Programs Administration, Washington, D.C. January 5, 1988.

Index to Preemption of State and Local Laws and Regulations under the Hazardous Materials Transportation Act (49 App. U.S.C. 1801 et seq.). U.S. Department of Transportation, Research and Special Programs Administration, Washington. D.C. January 8, 1988.

Quarterly Radioactive Materials Transportation Legal Developments Report. Battelle Project Management Division, Office of Transportation Systems and Planning, Columbus, Ohio. August 1988.

Quarterly Radioactive Materials Transportation Legal Developments Report. Battelle Project Management Division. Office of Transportation Systems and Planning, Columbus, Ohio. February 1989.

Southern States Energy Board Legislative Digest 1986. Southern States Energy Board, Atlanta, Georgia. September 1986. 
Southern States Energy Board Legislative Digest 1987. Southern States Energy Board, Atlanta, Georgia. October 1987.

Transportation of Radioactive Materials: A Summary of State and Local Legislative Requirements for the Perlod Ending December 31.1985. Oak Ridge National Laboratory, Oak Ridge, Tennessee. April 1986. (ORNL/TM-9985).

"Transportation Routing Issues Related to the Shipments of High-Level Nuclear Waste." OCRWM Backgrounder. U.S. Department of Energy. Office of Civilian Radioactive Waste Management, Washington, D.C. January 1987. (DOE/RW-0122). 

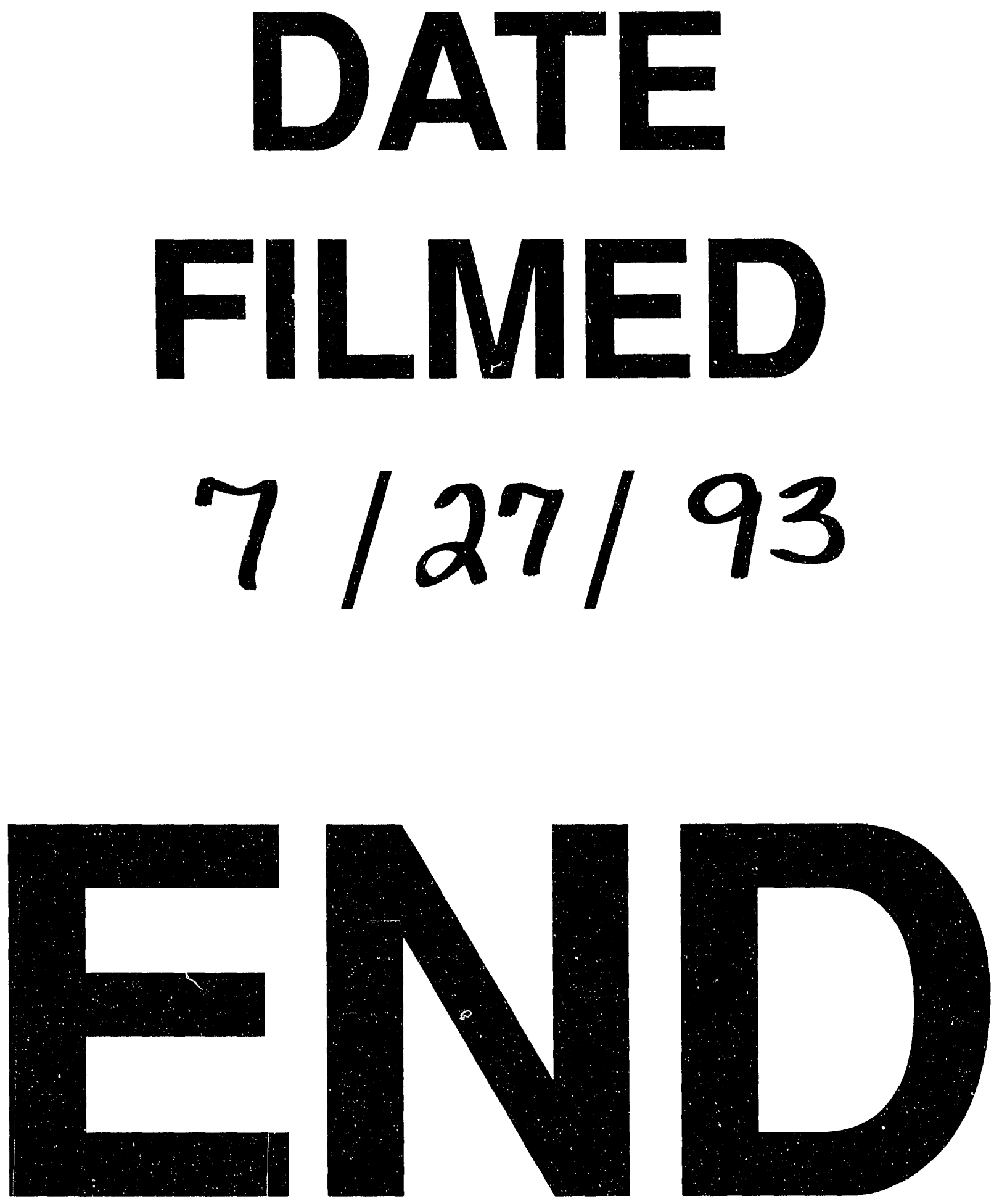
